\title{
EGY CIVIL SIKERTÖRTÉNET: SZÁDVÁR MEGMENTÉSE
}

\author{
Dobos János - Gál VikToR - P. HoRváth VikTória \\ Magyar Régészet 9. évf. (2020), 1. szám, pp. 70-75. doi: https://doi.org/10.36245/mr.2020.1.8
}

A Szádvárért Baráti Kör 2006-ban alakult egy internetes fórumon, lelkes várbarátok összefogásával abból a célból, hogy az egyik pusztuló hazai középkori várunk megmentésén dolgozzanak. Az alapitó tagok választása a Borsod-Abaúj-Zemplén megyei Szögliget település külterületén álló Szádvárra esett. Az ország egyik legnagyobb alapterületü középkori vára a nagyközönség elött akkor szinte ismeretlen volt. A korábbi határsávban évtizedekig elzárt területen fekvö romokat beboritotta az aljnövényzet, a falak megközelithetetlenek voltak (1. kép). Az egyesület müködését és az eredményeket bemutató cikkünkben arra a kérdésre is választ keresünk, hogy miért sikerült Szádváron immár másfél évtizede közösségi régészeti programokat létrehozni, és milyen problémákkal néznek szembe azok, akik hasonló célokat tüznek ki maguk elé.

Az egyesület célja kettős: egyrészt Szádvár megmentése - az ott található régészeti müemléki értékek megtartása, feltárása, konzerválása -, hozzájárulva az épített kulturális örökségünk megóvásához; másrészt a vár környezetében élők megmozdítása és megsegítése, a helyszínnek és környékének a népszerüsítése. A vár kedvelt turistacélponttá emelése - mely nagymértékben hozzájárulhat a helyi turizmus fellendüléséhezegyre növekvő bevételt jelenthet a helyi szállásadók, szolgáltatók számára.

Az egyesület mindezt a helyi és illetékes intézmények, szervezetek támogatása, illetve az önkéntesek és a Szögligeten élök együttmüködése nélkül nem tudná megvalósítani. Az egyesület évente három rendezvényen várja az önkénteseket, melyek közül a nyaranta szervezett egyhetes ásatási program a legnépszerübb. A feltárások a miskolci Herman Ottó Múzeum régészeinek felügyelete mellett alkalmanként mintegy 50-60 fó részvételével, 5-8 kutatóárokban folynak.

A múzeum szakmai vezetésével 2010-2017 között 45 szelvényben, mintegy $620 \mathrm{~m}^{2}$-en folyt régészeti feltárás (2. kép). Az egyesület által koordinált állagmegóvási munkákat megelőző, majd a rom egyéb területeit is vizsgáló, szondázó jellegü ásatások során részben megismerhetővé vált a vár - még mindig nem teljes - építéstörténete, valamint a belső helyiségeinek kiterjedése, funkciója (3. kép). Az önkéntesek munkájának köszönhetően jelentős mennyiségü, elsősorban 16-17. századi leletanyag került be a múzeum gyüjteményébe. A várbeli élet számos aspektusát reprezentáló tárgyak mellett összeomlott cserépkályhák, kemencék és egy 17. századi konyha sütés-főzés céljára használt nyílt tüzhelyének maradványa is napvilágra került. A restaurált leletanyag egy részét Szögligeten, egy kis kiállítás keretében tekinthetik meg az érdeklődő látogatók.

A Nemzeti Várprogram turisztikai fejlesztését előkészítő megelőző feltárások során - szintén az egyesület önkénteseinek segítségével - újabb $720 \mathrm{~m}^{2}$

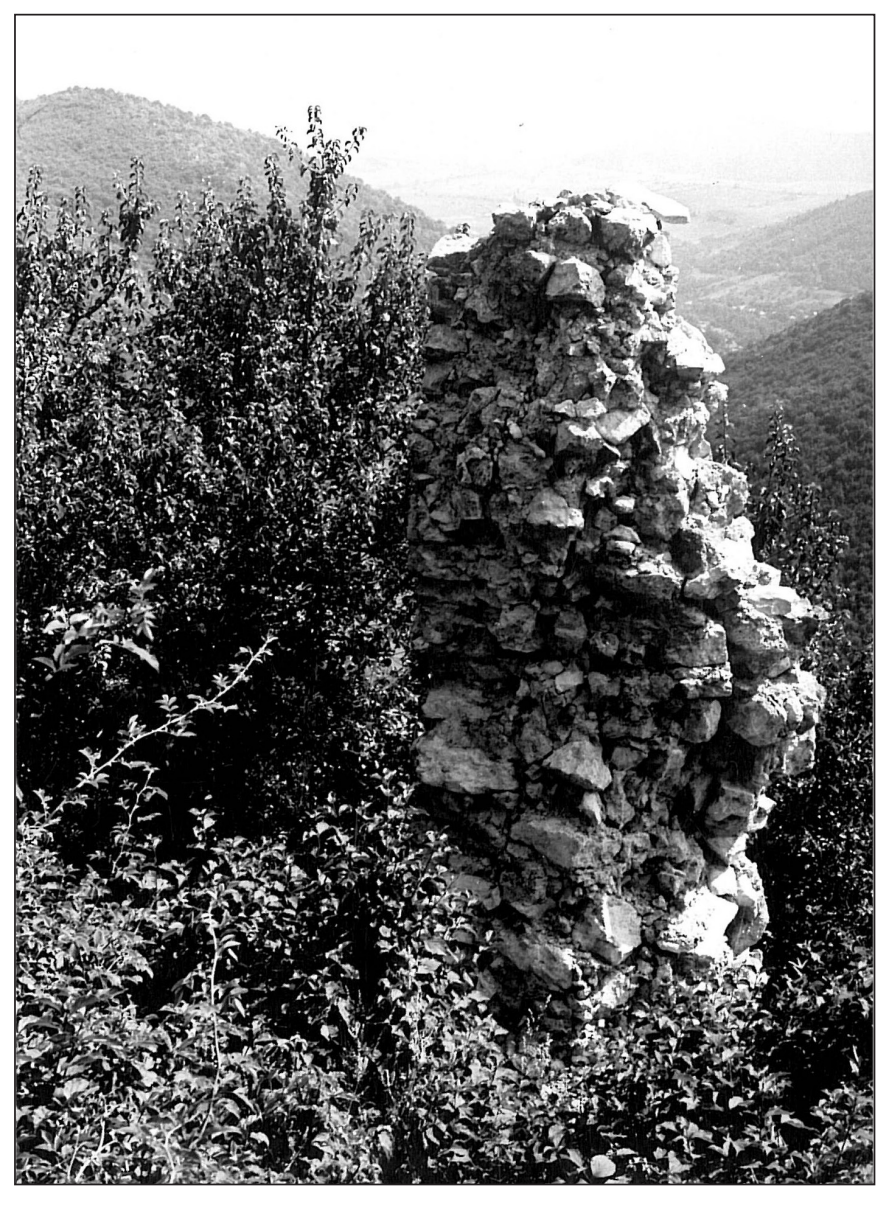

1. kép. Szádvár romjai, 1965

(Herman Ottó Múzeum, Fotó- és Negatívtár 23495) 
Dobos János - Gál Viktor - P. Horváth Viktória • Egy civil sikertörténet: Szádvár megmentése

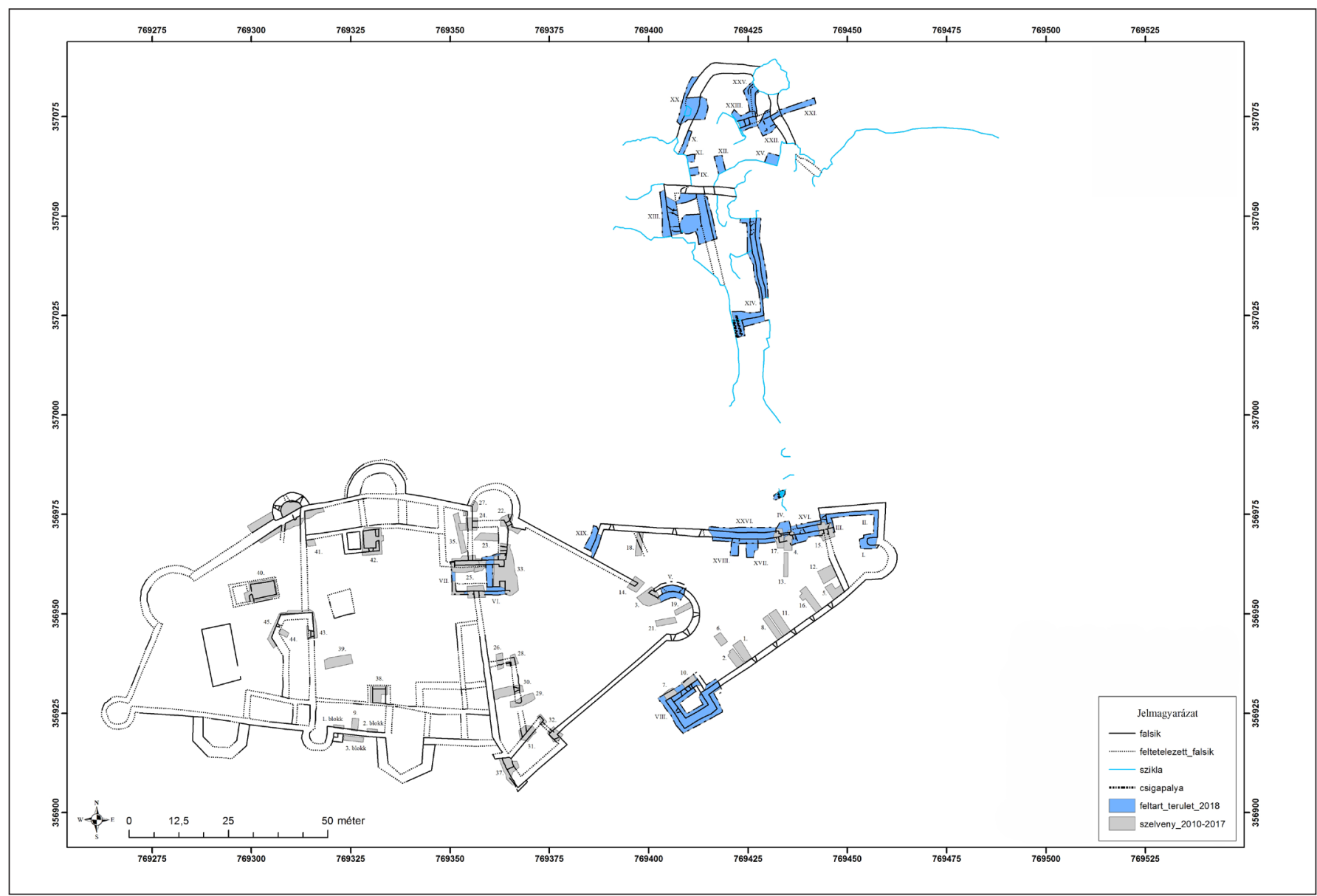

2. kép. Összesitö feltárási alaprajz, 2019 (Herman Ottó Múzeum)
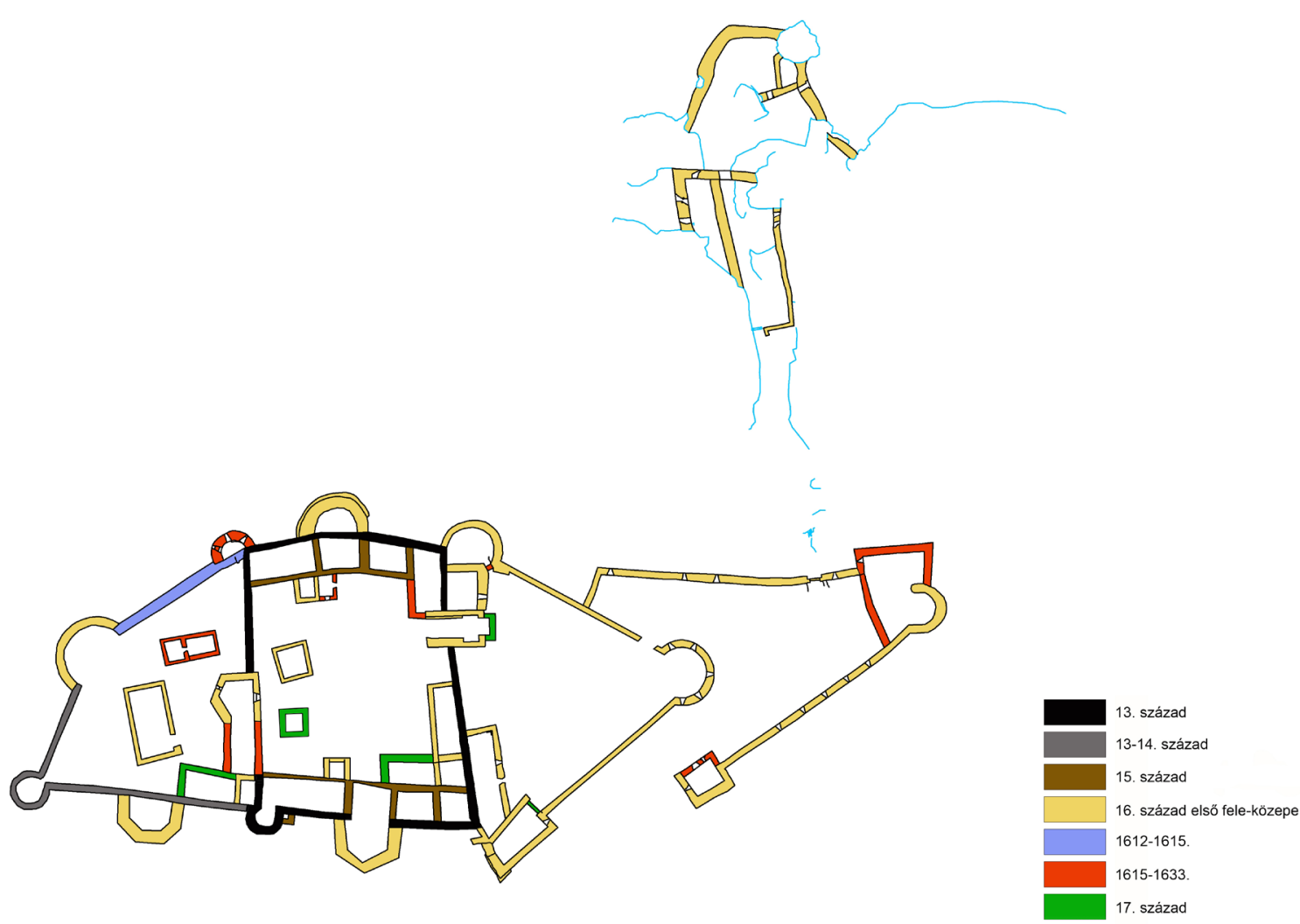
felület kutatására nyílt lehetőség 2018-ban. Az elsösorban a várhegy északi oldalában megbújó Alsóvár területére koncentráló ásatások eddig még nem ismert és nem is sejtett építészeti, valamint hadászati jellegű információval bővítették a várról szerzett ismereteinket. A négy hónapos intenzív munka végén - mely a Felsővár keleti várrészét és a belső vár kaputornyát is érintette - a 16. század középső harmadában egy egységes építészeti koncepció alapján létrehozott többlépcsős védelmi rendszer képe rajzolódott ki. Az Alsóvár mindeddig ismeretlen, egyszerü gyalogkapujának, az elöször 1570ben említett, és Szádvár jellegzetességének számító felvonószerkezet - a „csiga” - nyomvonalának feltárásával a késő középkori közlekedési rendszer is megismerhetővé vált (4. kép).

A szervezet nem titkolt célja, hogy egyre több résztvevő és látogató jelenjen meg a rendezvényeken, kapjon kedvet a csatlakozáshoz önkéntesként, majd az egyesület tagjaként. A Baráti Kör mögött ma sem áll vállalkozás, sem folyamatos anyagi támogatást nyújtó háttérszervezet, az együttmüködés ezért kezdettől kulcsfontosságú szerepet játszott. Az egyesület eredményes tárgyalásokat folytatott többek közt a miskolci Herman Ottó Múzeummal, Szögliget önkormányzatával, a mindenkori örökségvédelemért felelős hivatallal, a terület tulajdonosával és kezelöjével, az Aggteleki Nemzeti Park Igazgatóságával, továbbá más civil egyesületekkel. Az együttmüködő partnerek részben a szakmai célok eléréséhez adnak segítséget, mások eseti anyagi támogatást nyújtanak, és akadnak olyanok, amelyek a szervezett programok résztvevőit biztosítják - cserébe az adott szervezet programjait az egyesület önkéntesei is segítik.

Kérdés, hogy mitől müködik egy ilyen kezdeményezés, és mi teszi fenntarthatóvá. Először is nagyon szerencsés volt a választás, mivel Szádvár esetében kétségkívül szerepet játszik a hely különlegessége. Az a tény, hogy egy szinte ismeretlen, mégis jelentős és hatalmas kiterjedésű középkori várrom rejtőzik egy nemzeti park erdeiben, csodálatos természeti környezetben, mindentől távol, már

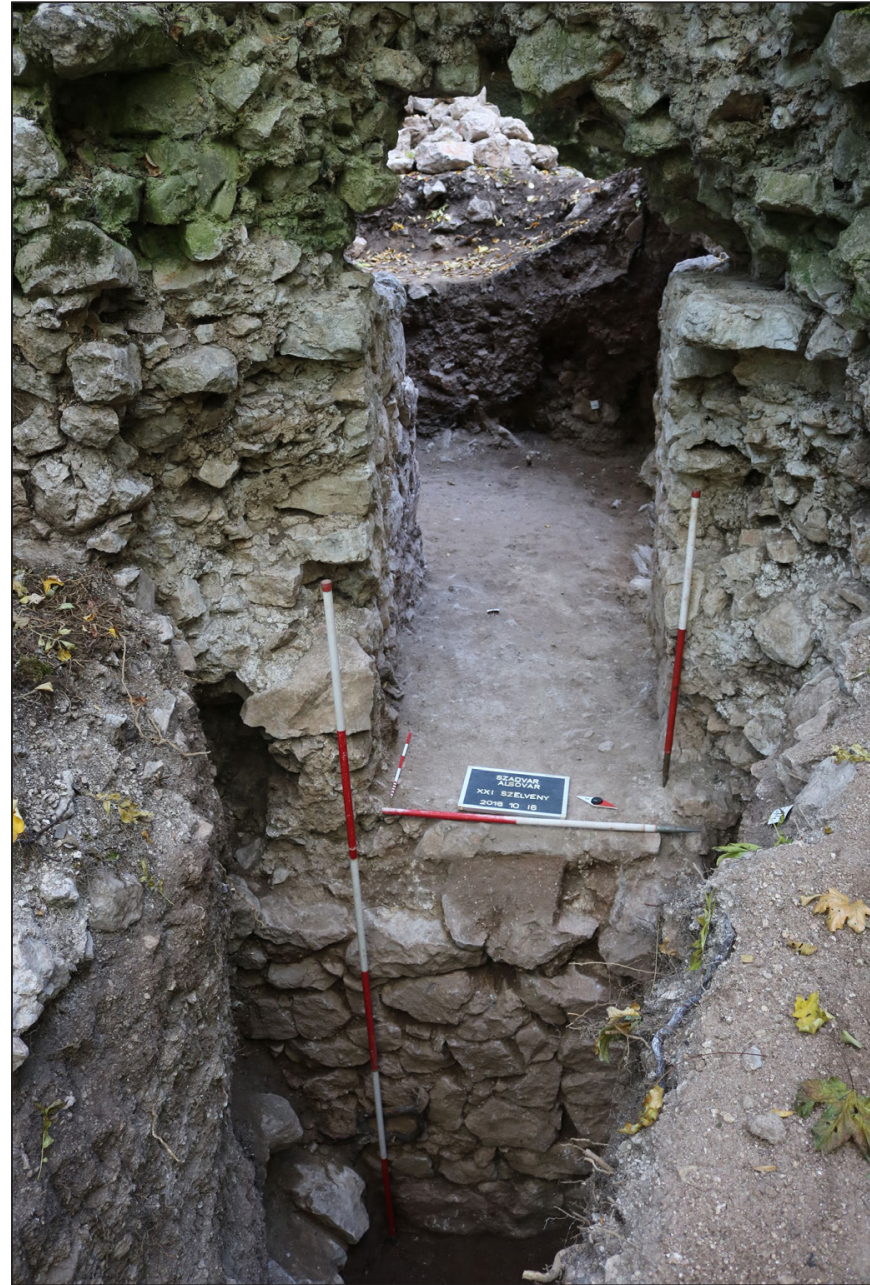

4. kép. Szádvár - Alsóvár, a gyalogkapu kelet felöl, 2018 (Herman Ottó Múzeum)

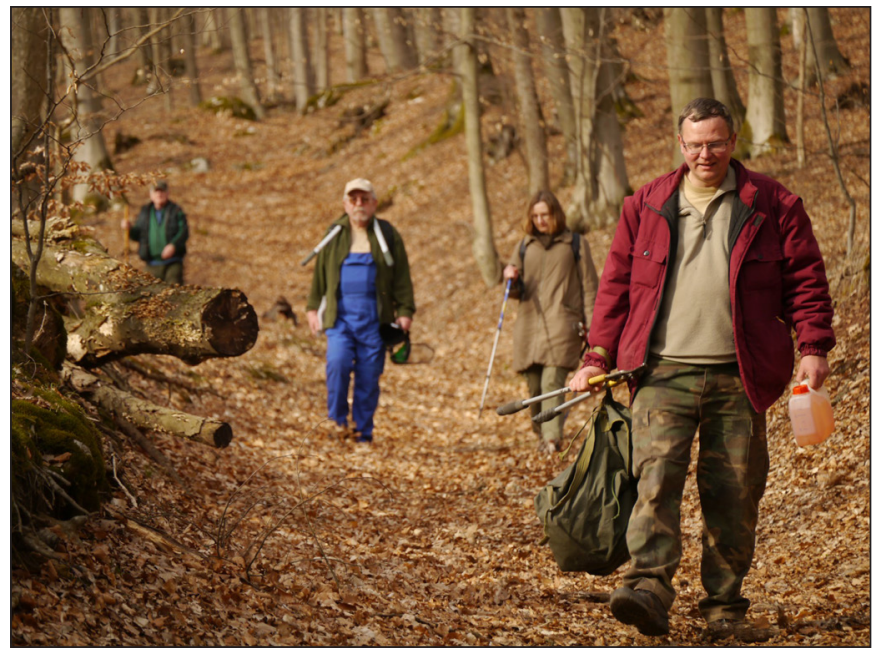

5. kép. Egy dolgos nap végén (Fotó: Szádvárért Baráti Kör) önmagában vonzó lehet a modern ember számára, ahol hátrahagyhatja a nyüzsgő városi életet és annak minden velejáróját. Az sem kérdés, hogy a kezdeményezők és az első önkéntesek olyan körböl kerültek ki, akik a várak, a várromok, a kulturális örökség középkori emlékei iránt eleve komolyabb érdeklődést mutattak. Ugyanakkor fontos megjegyezni, hogy az első években a munka a vár megtisztításában, a fák, a bokrok és az aljnövényzet kiirtásában merült ki. Az első ásatások csak a Szádvárért Baráti Kör alapítása utáni harmadik évtől kezdődtek meg (5. kép). 


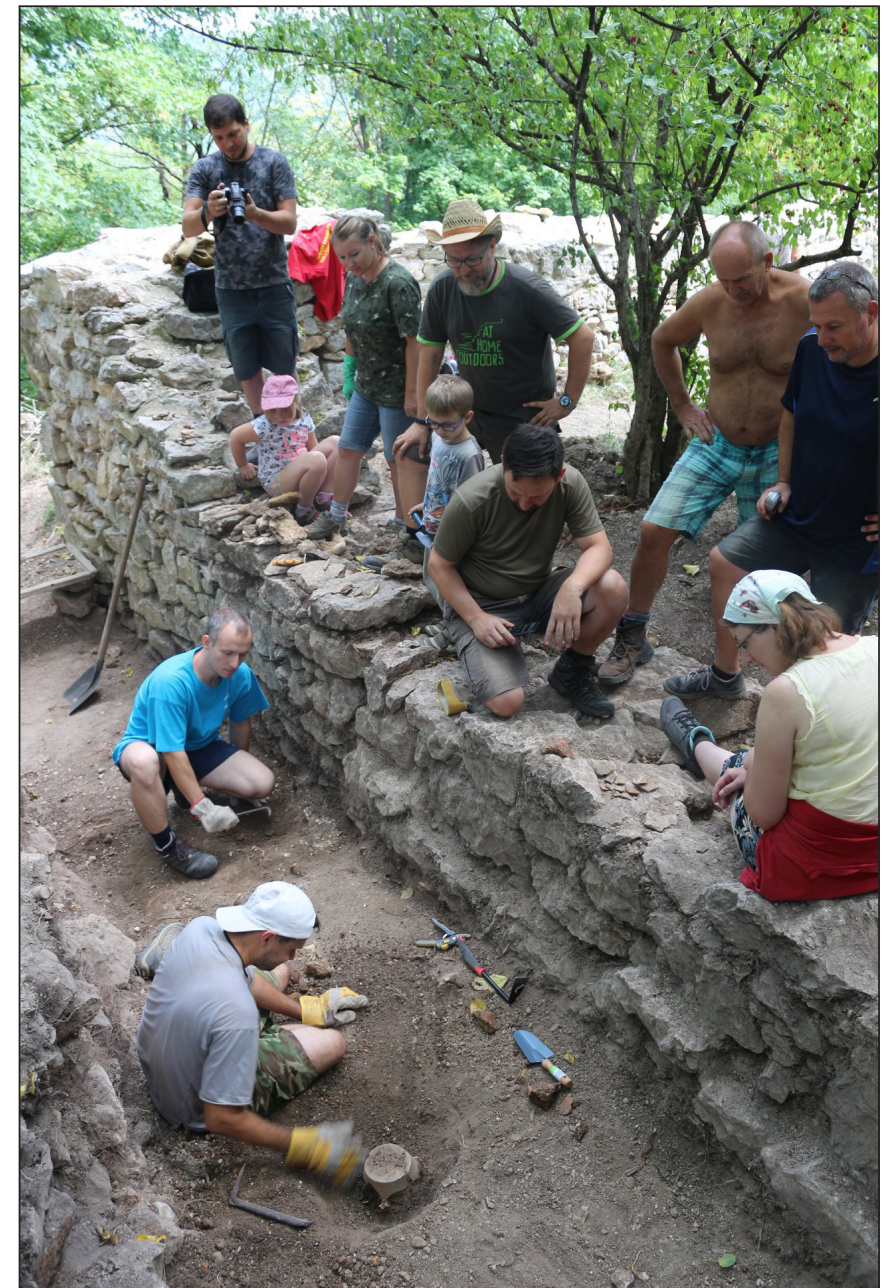

6. kép. Önkénteseink a nyári Vármentö Héten (Fotó: Szádvárért Baráti Kör)

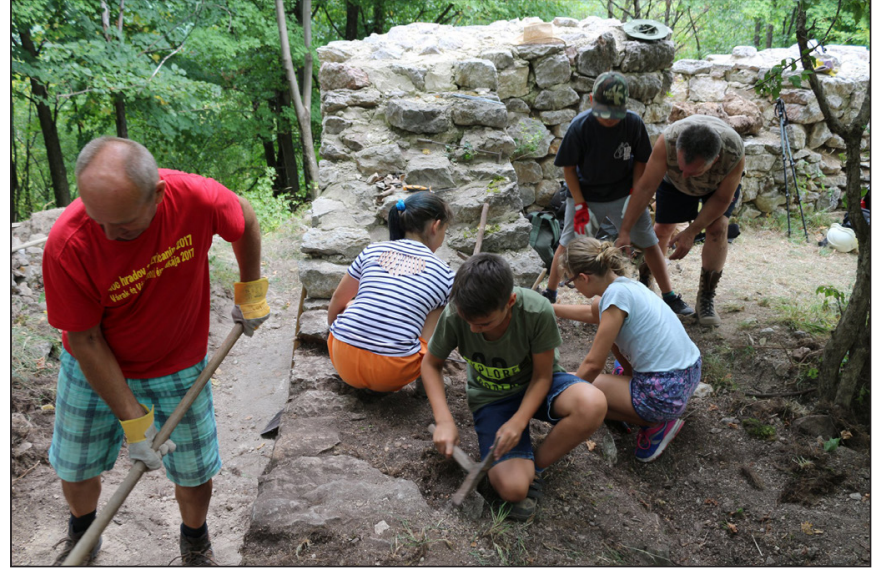

7. kép. Önkénteseink a nyári Vármentö Héten (Fotó: Szádvárért Baráti Kör)

Az egyesület a komolyabb érdeklődést és az önkéntesek megtartását azonban egyértelmüen a rendszeres nyári feltárásoknak köszönheti. De miért lesz valakiből önkéntes „régész”? Itt a felfedezés és a kincskeresés izgalmán, a „kicsit minden ember régész" gondolatán túl számolhatunk az önkéntesség legfontosabb mozgatójával, a belső késztetéssel az iránt, hogy az embereknek örömöt okoz, ha hozzájárulhatnak a közös kulturális örökség megóvásához (6-7. kép). Ez egyértelmúen erősíti és kielégíti a közösséghez tartozás iránti igényünket is. A szervezések során ezért hangsúlyossá vált a közösség építése mellett az emberek szakmai tájékoztatása: a témában érintett előadókat, régészeket, építészeket hívunk meg más várakból, múzeumokból.

A szakma visszhangja azonban kettős. Az örökségvédelemmel foglalkozó intézmények és szakmai szervezetek Podmaniczky-díjjal, Kós Károly-díjjal és Forster Gyula-emlékéremmel ismerték el az egyesület munkáját. Szögliget Önkormányzata „Szögligetért” emlékplakettet és oklevelet adományozott az egyesületnek. Esetenként viszont olyan visszajelzések is eljutnak az önkéntesekhez, melyek szerint a munkájukat „hobbirégészetnek”, „kincskeresésnek” értékelik, ami demotiváló lehet. A motiváció megtartása azonban fontos, hiszen az egyesületnek nincs fizetett tagja, és a munka során minden önkéntesnek a saját szabadidején kívül komoly anyagi áldozatot is hoznia kell azért, hogy a régész keze alatt dolgozhasson.

A lelkesedésnek, amely ehhez a motivációhoz elengedhetetlen, szintén kettős hatása van. Az önkéntesekben azt a hamis érzetet keltheti, hogy szakmai háttér nélkül, autodidakta módon is lehet bárkiből régész, aki képes szakmai döntéseket hozni. Az ebböl fakadó ellentéteket megfelelöen kell kezelni, tudatosítani, miszerint nem az önkéntesek határozzák meg a szakmai munkát még akkor sem, ha esetenként annak ütemezését a régész igazíthatja az önkéntesek által érdekesebbnek tartott területek felé.

Az önkéntesek felkutatásának és bevonásának ma már elsődleges színtere az internet, a közösségi média. Az események szervezése alapvetően ezen a felületen zajlik, ezért kiemelten fontos azokat a lehetőséget megragadnunk, ahol a népszerüsítés eszközeivel élhetünk. Az évek során saját honlappal, közösségi oldalakkal, videócsatornával igyekeztünk felhívni a reményteli önkéntesek figyelmét a csatlakozás lehetőségére. Ennek kapcsán megfigyeltük, hogy a várak szerelmesein túl érdemes a túrázókat, a természetkedvelőket, a gasztronómia élvezőit, illetve más, különböző érdeklődésű csoportokat is megcéloznunk a népszerüsítéssel, hiszen a munkában való részvétel nem igényel kizárólag történelmi érdeklődést. A tevékenységünkkel 


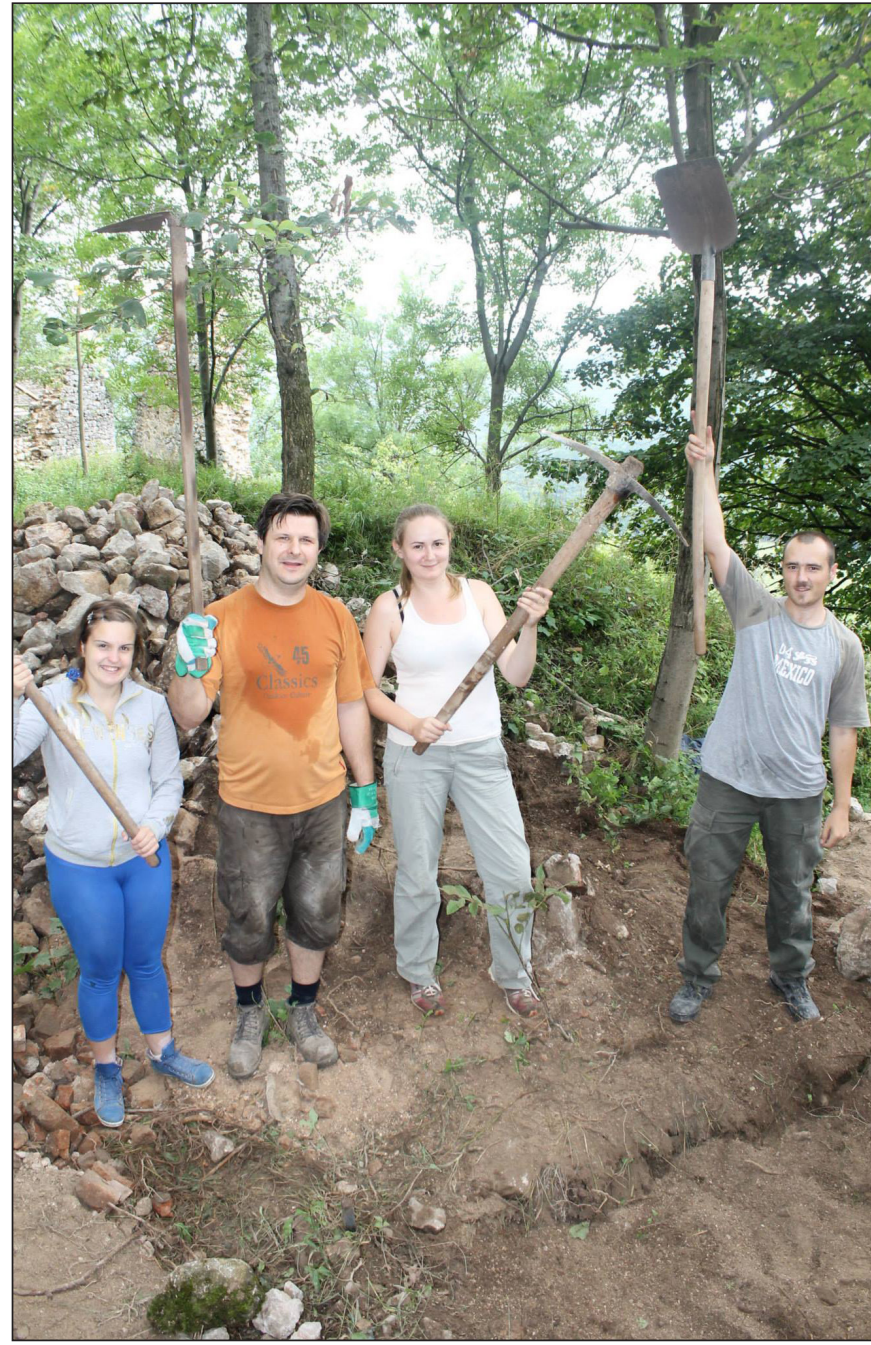

8. kép. Önkénteseink a nyári Vármentö Héten (Fotó: Szádvárért Baráti Kör)

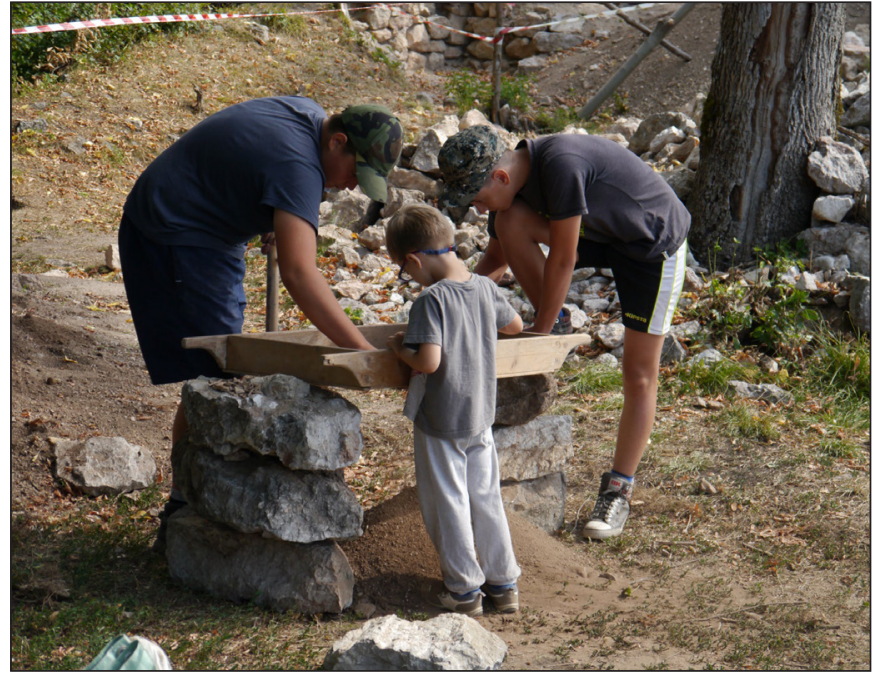

9. kép. Önkénteseink a nyári Vármentö Héten (Fotó: Szádvárért Baráti Kör)

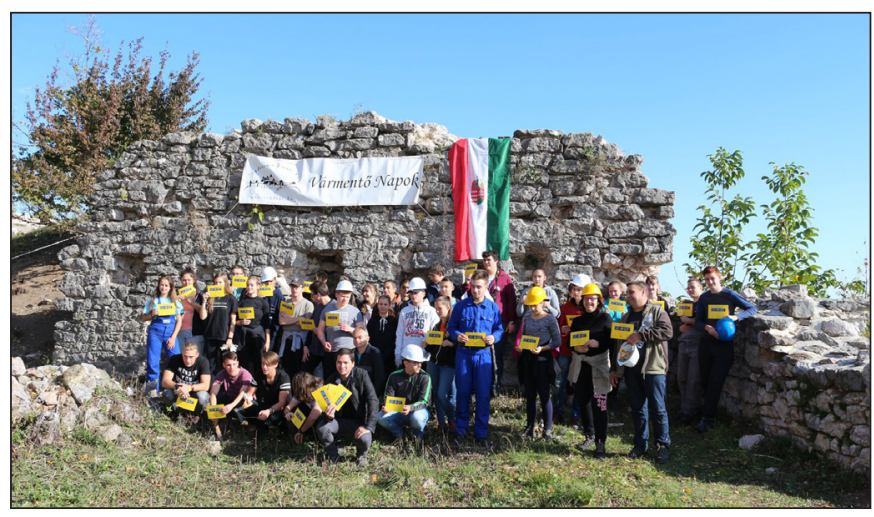

10. kép. A Vármentö Napok visszatérö résztvevői a Győri Szakképzési Centrum Hild József Épitőipari Szakgimnáziuma diákjai (Fotó: Szádvárért Baráti Kör)

kapcsolatos kérdőívünk eredményéből kiderült, hogy sokakat az önkéntes munka, a környék felfedezése ugyanúgy motiválja, mint a középkori vár történetének a megismerése.

A közösségi médiával kapcsolatban arra is figyelünk, hogy a munkáról készült képek, videók publikálása ne sértse a régész vagy a tervező jogait, szakmai érdekeit. Így az együttmüködésnek ez is fontos eleme.

Az elért eredmények és a folyamatos állagmegóvásra, valamint a müködésre vonatkozó pályázatok, illetve az említett elismerések közvetett eredménye a Nemzeti Várprogramban csúcsosodott ki, amikor Szádvár is felkerült a támogatott várak listájára. Ez meghozta azt az ismertséget, amit az alapítók 2006-ban célul tüztek ki. De ezzel nem ér véget sem a Szádvárért Baráti Kör, sem az ott végzett közösségi régészeti munka, hiszen a Nemzeti Várprogram csak a vár töredékére terjed ki, továbbá a hosszú távú kezelés és hasznosítás is elképzelhetetlen az önkéntesek tevékenysége nélkül (8-9. kép).

Szívből reméljük, hogy a csaknem tizenöt éve tartó lelkesedés - bár változó összetételü önkéntes sereggel - továbbra is elég lesz ahhoz, hogy a megkezdett munkát évröl évre elösegítse, bevonva minél több érdeklődőt a saját kulturális örökségünk megismerésébe és megmentésébe. 2020-ban a munkában résztvevő valamennyi félnek el kell fogadnia, hogy csakis nyitott, őszinte hozzáállással, és az erőforrások megfelelő felhasználásával tartható fenn az eredményes együttmüködés. Szerencsére az országban egyre több olyan pozitív példa akad, ahol a szakma képviselői hasznosítani tudják a civil érdeklődők erőforrásait fizikai vagy szellemi hozzájárulás formájában. Ez utóbbiak több szempontból is profitálhatnak az eseményeken való részvételböl. Arra kell tehát törekednünk, hogy ne utasítsuk el egymást, hanem keressük a megoldást, hiszen örökségvédőként a szándékaink és a céljaink közösek (10. kép). 
Dobos János - Gál Viktor - P. Horváth Viktória • Egy civil sikertörténet: Szádvár megmentése

AJÁNLOTT IRODALOM

Détshy, M. (1969). Egy ismeretlen magyar vár - Szádvár. Herman Ottó Múzeum Évkönyve 8, 143-186.

Fejes, E., Hancz, E., Kovács, L., König, F., László, J., et al., (2014). Szádvár: Rekonstrukciós elképzelések. Szögliget: Civertan Grafikai Stúdió, Szádvárért Baráti Kör.

Gál-Mlakár, V. (2011). Szögliget-Szádváron végzett állagvédelmi munkák módszerei és tapasztalatai. In Terei Gy., Kovács Gy., Domokos Gy., Miklós Zs. \& Mordovin M. (szerk.), Várak nyomában - Tanulmányok a 60 éves Feld István tiszteletére (pp. 63-72). Budapest: Castrum Bene Egyesület, Civertan Grafikai Stúdió.

Gál, V. (2016). Adatok Szádvár 1567-es ostromához. In: Kósa P. (szerk.), Várak, kastélyok, templomok: Évkönyv 2016 (pp. 80-85). Kökény: ZIMédia.

Gál, V. (2019). Szögliget-Szádvár 2018. évi régészeti kutatásának eredményei. Castrum 22 (1-2), 189-212.

Gál, V. \& Kelemen, B. Z. (2014). Ledentu 3D-ben - Szádvár tömegrekonstrukciós kísérletének forrásai és látványvilága. Archeologia - Altum Castrum Online, A Magyar Nemzeti Múzeum Visegrádi Mátyás Király Múzeumának Középkori Régészeti Online Magazinja. http://archeologia.hu/content/archeologia/257/ szadvaar-kelemen-gal-2.pdf Letöltés: 2020.02.07.

Kelemen, B. Z. (2017). Állagmegóvási munkák Szádváron. In Kósa P. (szerk.), Várak, kastélyok, templomok: Évkönyv 2017 (pp. 110-111). Kökény: ZIMédia.

Szádvárért Baráti Kör (2016). Egy civil sikertörténet. Szádvár megmentése. Szögliget: Szádvárért Baráti Kör. 